\title{
Biosafety rules will regulate international GMO transfers
}

\begin{abstract}
London. Signatories to the United Nations Convention on Biological Diversity, which concluded their second annual conference in Jakarta last week, have agreed to formulate an international protocol regulating the transfer of genetically modified organisms (GMOs) between states.
\end{abstract}

The agreement represents a compromise between the Group of 77 (G77) countries, which favoured early enactment of a comprehensive protocol on biosafety, and the industrialized nations, which have been seeking the adoption of looser guidelines.

A group of experts has been given the task of working out details of the protocol, which will not come before the convention's signatory nations until at least 1999. The protocol will regulate accidental releases of modified organisms in transit. But it will not extend to regulating the handling and domestic use of GMOs, a goal enshrined in the biodiversity convention, signed at the Rio Summit in 1992.

Last week's agreement is largely the work of environment ministers from the Euro-

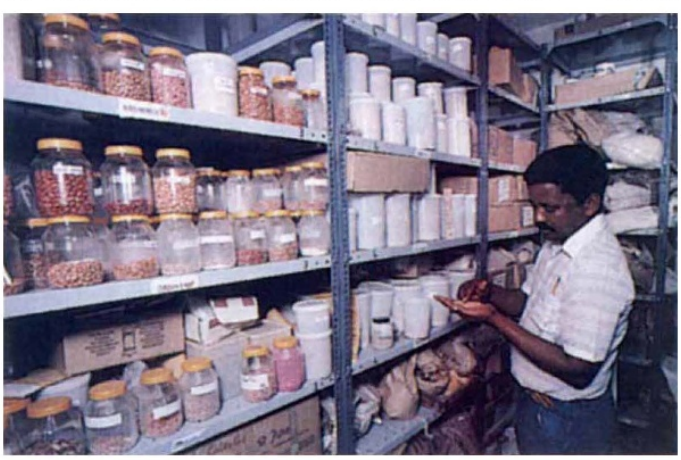

Open for business? Gene bank at Sebele, Botswana. test and relcase "potentially dangerous and self-replicating organisms in countries with weak or non-existent biosafety laws".

The EU maintains that domestic laws on biosafety should be the responsibility of national governments, not of the UN. Calestous Juma, the new executive secretary of the biodiversity convention, argues that such countries can now rely on UN biosafety guidelines - to be finalized next month as a basis for national legislation.

Apart from discussing biosafety, delegates representing 117 of the convention's 134 signatories passed a mandate urging governments to conserve marine and coastal biodiversity. The United Nations Environment Programme also used the conference's second day to launch its long-awaited 1,000page inventory of the Earth's biodiversity.

But several issues remain pending. For example, a decision on the terms under which companies should be allowed access to the genetic resources of other countries, and a debate on the patenting of indigenous innovations, were both put off to next year's meeting in Argentina.

Similarly, whereas the Jakarta conference agreed on a two-year pilot phase for the so-called 'clearing house' on scientific and technological cooperation, developed countries are thought to be cautious about the terms and nature of the information to be made available, which have yet to be discussed.

One of the Jakarta meeting's more controversial resolutions was an invitation to the World Trade Organization (WTO) to prepare a report on the relationship between

pean Union (EU), spearheaded by Britain. The present terms were agreed by EU ministers at a meeting in Luxembourg in July. EU delegates to the biodiversity conference then successfully persuaded G77 waverers at the Jakarta meeting to support the new alternative. Reaction to the agreement, reached on the conference's penultimate day, has generally been favourable.

Andrew Dickson, a spokesman for the International Bioindustry Forum, describes the protocol as a relevant, welcome and sensible conclusion and expresses satisfaction that "industry's voice has been heard more strongly than hitherto". Nancy Vallejo, coordinator of international treaties at the World Wide Fund for Nature, said that agreement on a protocol was "a significant result".

But not everyone has been persuaded. Ronnie Hall, for example, of Friends of the Earth, says legislation on the domestic handling and use of GMOs is still needed. Without such measures, she adds, companies can

\section{Swiss researchers adopt voluntary rules on exports}

London. Swiss research institutions, keen to counter criticism of the lack of rules covering the export of genetically manipulated organisms (GMOs) to researchers in other countries, have agreed to adopt a set of voluntary safety guidelines covering such exports.

The new guidelines have been drawn up by the Swiss Interdisciplinary Committee for Biosafety in Research and Technology (SCBS), and are expected eventually to be given legal backing. They include the requirement on an exporting laboratory, whether public or private, to notify an appropriate agency in the recipient's country of the nature and quantity of the organisms involved, and to provide the agency with a brief summary of "the assessment of risk to human health and the environment".

The change has been prompted partly by a widely publicized incident last year, when the environmentalist group Greenpeace intercepted a package of genetically modified rice seeds being sent to the International Rice Research Institute in the Philippines.

"One reason for this Greenpeace action was to alert the public to the fact that no legally binding regulations exist in Switzerland, or internationally, covering the exports of GMOs to be used in field trials," says Karoline Dorsch-Häsler, secretary to the committee. The public dispute took place, she points out, despite the fact that the Swiss researchers had obtained permission from the Philippine government to import the rice.

Under the new guidelines, which will allow the committee to keep track of all GMO exports from Switzerland, any exporter has to obtain the prior "informed agreement" of any country to which GMOs are sent. The exporting organization also has a responsibility to comply with the appropriate safety procedures in the receiving country.

The guidelines are based on procedures that have been drawn up by the United Kingdom and the Netherlands, which were recently applied for the first time to a bilateral agreement between Britain and Argentina (see Nature 377, 97; 1995).

Although they do not yet have the force of law, the guidelines have already been accepted by most of the bodies responsible for publicly funded research in Switzerland, as well as by the Society of Swiss Chemical Industries.

David Dickson 